\title{
A Thematic Analysis of Maria Irene Fornes' Fefu And Her Friends in A Psychoanalytic Feminist Approach.
}

(A Part of an MA Thesis entitled as "Interdisciplinary Feminism: A Thematic Study of Maria Irene Fornes' Fefu and Her Friends and Caryl Churchill's Top Girls")

\section{Avan Taha Saleh}

Department of Electrical Engineering, College of Engineering, Salahaddin University, Erbil, Kurdistan Region Iraq avan.saleh@su.edu.krd

\section{Asst. Prof. Dr. Tara Dabbagh}

Department of English Language, College of Languages, Salahaddin University, Erbil, Kurdistan Region, Iraq tara.dabbagh@su.edu.krd

\section{ARTICLE INFO}

\section{Article History:}

Received: 3/7/2019

Accepted: 18/8/2019

Published: Winter 2021

\section{Keywords:}

Psychoanalytic

Feminism, Fornes, Oedipus Complex, the Symbolic Order, Gendered Identity.

Doi:

\section{ABSTRACT}

The quest for a female subjectivity and a unique female voice that is neither the derivation nor the other version of that of the male has long been one of the main concerns of feminism. However, with the advent of psychoanalysis and its predominance in the world of literary theory and criticism, feminists could finally arrive at the theoretical basis for their assumptions about the nature of femininity through which they tried to, on the one hand, explore the possibilities of formulating a subjective female entity, and on the other, challenge the hindrances that stand in the way of achieving a female individuality. Psychoanalytic feminism, as the main focus of this paper, is best seen as merging between the principles of feminism and psychoanalysis to shed light on the deep-rooted gender stereotypes that make patriarchy unavoidable.

This paper attempts to show how feminism and psychoanalysis work together through a thematic 
analysis of Maria Irene Fornes' play, Fefu and Her Friends (1977). The play which consists of an all-female cast, gives various encounters of female issues in a male-dominated environment. Both the play Fefu and Her Friends and the approach of psychoanalytical feminism work reciprocally throughout the paper to highlight the internal psychological struggles of women based on sex/gender, to show how women view and place themselves in a male-dominated society, and how they value their relationship with both themselves and their surroundings.

\section{INTRODUCTION}

The latter part of the twentieth century is characterized by a period of turbulent changes in the way literature made its way into the dominant issues that Western culture was then witnessing. Theatrical productions in general and playwrights specifically, started to shift their focus away from more abstract subjects onto the major and more immediate and pressing political, social, and, institutional subjugations overpowering the life of the modern individual. Using a multitude of distinctive theatrical conventions, contemporary theatre directed itself towards a fusion of realistic and theoretical or philosophical concepts to address these subjugations. Of the highly notable topics to be seen in this theatre are gender-related as most importantly, the period witnessed the flowering of a number of female playwrights who raised such concerns. Touching on matters both universal and local, these playwrights started posing questions as to how the western culture views women. Maria Irene Fornes (1930-2018) is considered as one of the most prominent female playwrights of this era whose play Fefu and Her Friends (1977) will be the chief point of analysis in this paper. Born in Havana, Cuba, Maria Irene Fornes immigrated to the United States at the age of 15 . She turned to playwriting at the age of 30 . It is worth mentioning that all her writings were done in her second language, English. According to Robinson (1997, p.91), "Fornes...said that she never writes her plays in Spanish, that the rigors of working in a second language keep her honest: They enforce 
the discipline any writer hopes to practice". Thus, she among others stands as an account for the divergent culture of the United States. This diversity in turn, helped her shape multiple characters possessing different traits and dilemmas. Fornes' plays are characterized by being structurally innovative, highly symbolic, and, embracing elements of cruelty and dark humour. One of the main forces that attracted Fornes to playwriting was her fascination with Samuel Beckett's Waiting for Godot (1953). As a result, elements of the Theatre of the Absurd featured clearly in her early plays. This gradually faded away, however, by the time she started writing Fefu and Her Friends (Wilson and Goldfarb, 2000, p. 476).

Written and directed by Fornes herself, Fefu and Her Friends, is set in the spring of 1935 in New England. The actions of the play take place at Fefu's home over the course of one day during which the characters are rehearsing for a fundraising event to aid them with their project about education. What is striking about the play is that it encompasses an all-female cast with no male characters ever appearing on stage. Although the play was produced at a time when Fornes had already been recognized as a reputable writer, it is, nevertheless, considered to be of the landmarks in her literary career. As asserted by Wilson and Goldfarb (2000, p.476) "in the 1970s, Fornes continued to search for her own unique voice and many critics believe that she found it in Fefu and Her Friends".

It is true that Fefu and Her Friends takes a more realistic approach than her former plays, yet Fornes still manages to touch on issues that linger beneath what outwardly seems to be the reality of both contemporary individuals and the society they belong to. For realism for Fornes and her contemporaries as Saddik (2007, p. 13) puts it, did not remain inside the framework of "traditional realism, with its focus on surface representation and insistence on rationality and order [but, it rather focused on] offering more subjective, flexible interpretations of reality". Hence, by letting the audience spend an entire day with eight women of different personalities and life experiences, the play offers much room for analysis related to gender and feminism. 


\section{QALAAI ZANISTSCIENTIFIC JOURNAL \\ A Scientific Quarterly Refereed Journal Issued by Lebanese French University - Erbil, Kurdistan, Iraq \\ Vol. (6), No (1), Winter 2021 \\ ISSN 2518-6566 (Online) - ISSN 2518-6558 (Print)}

Hereby, Fornes' attraction towards the techniques of the avant-garde theatre and Theatre of the Absurd contributes greatly in her dealing with her subject matter differently, despite the apparent conventional realism. Hence, the feministic tone in Fefu and Friends does not merely show a physical or concrete kind of female oppression, but also explores how women have become prisoners of the constant sense of inferiority impressed on and engraved in their unconscious mind. Along the same lines Saddik states that:

Fefu and Her Friends, is a feminist play in that it deals with the social forces that silence and destroy women, both psychically and physically. The limiting patriarchal construction/destruction of female identity, the selfimposed internalized oppression that women experience, and the need for new, self-determined identities are central issues in the play. $(2007$, p.169)

By giving the female characters, each of whom is exposed individually in the play, the opportunity to express her real self freely and to act as herself in a world where no male power materially exists; the play manages to reveal much about the inner psychological effects of the patriarchal culture on women.

\section{Fefu and Her Friends in a Freudian Psychoanalytic Feminist Approach}

The fundamental psychoanalytical concepts laid down by Sigmund Freud can be regarded as one of the main initiating forces behind the concern of feminism with psychoanalysis. Almost most studies conducted in the psychoanalytical feminist field deal with a part or more of his theories, be it directly or indirectly. As argued by Zakin, this is so, largely, due to the fact that any theory related to psychoanalysis, is bound to deal with the concept of the unconscious and its connection with sexuality. Thus, further argues Zakin, what brings together all the distinct branches of psychoanalytic feminism is their shared background, 


\section{QALAAI ZANISTSCIENTIFIC JOURNAL \\ A Scientific Quarterly Refereed Journal Issued by Lebanese French University - Erbil, Kurdistan, Iraq \\ Vol. (6), No (1), Winter 2021 \\ ISSN 2518-6566 (Online) - ISSN 2518-6558 (Print)}

their regard for, and their slight borrowing of Freud's accounts of the unconscious (2011, p. 2).

According to Tong (2014, p. 127) "by no means was Sigmund Freud a feminist, yet psychoanalytic feminists...found in his writings clues about how to better understand the causes and consequences of women's oppression".

Freud's psychoanalytic theory and its later adaptations, helped psychoanalytic feminists expound much of the "biologically based assumptions about femininity [through which they] found original and compelling new psychic models for feminine identity" (Guerin et al., 2011, p. 261). Moreover, as Freud carried out his psychoanalytical practices upon his female patients and also on his two dedicated daughters Anna and Marie Bonaparte, the subjective narratives given by these female voices of their own interactions with their personal fantasies, fears, and illnesses, were the first of their kind to be expressed and accepted. For in Freud's days, psychological issues related to women, such as depression, were perceived as typical female problems for which the womb was thought to be responsible. Female patients with hysteria or other kinds of psychological problems could end up being isolated or even receive shock treatments. Hence, Freud's contribution, on the one hand, was to label women's psychiatric problems as real health issues which require medical treatment. On the other hand, Freud attempted to deal with his patients in a way as if he is reading them like texts or languages, emphasizing the textual nature of his cases and theories. This, along with Freud's other theories, opened the doors for the entry of female subjectivity into the world of literary criticism and analysis. This primacy of female subjectivity and female inner voice forms the particular interest of psychoanalytic feminists.

Nevertheless, Freud's ideas have been of great controversy among most feminists. Mainly and for the most part, his ideas were challenged by feminists to reduce the danger of them further providing the current patriarchal culture with additional clues to practice its power over women. The charge has been that Freud appears to be "proffering misogynist, and perhaps Procrustean, 
elaborations of psychic structuration, curtailing and diminishing the diversity of individual women's experiences into a restricted and unvarying formula that will fit within its own theoretical parameters" (Zakin, 2011, p. 2). The notion of the unconscious, Freud's theory of infantile sexuality, and his avid statements on the psychical procedures of the Oedipus complex, the castration complex and penis envy are the areas that form the utmost concern of the feminist thinkers working in the psychoanalytical field. For a better apprehension of why feminists found these concepts offensive, and how later on, proposed their own arguments about masculinity and femininity, it is necessary to have a brief look at what Freud meant by the above terms.

The essence of psychoanalysis lies in Freud's discovery of the concept of the unconscious. According to Freud, there is a dimension inside the human mind that cannot be fully accessed by consciousness. The unconscious, is a storehouse in which all the socially unaccepted desires, feelings, instinctual drives, and memories are suppressed and stored (Rivkin and Ryan, 2004, p. 389). In attempting to describe the processes by which the repressed thoughts and desires are forced back to the unconscious and/or which at times succeed to appear to consciousness; Freud maintained that the human psyche is divided into three parts: the id, the ego, and the superego.

As elaborated by Bressler, the id constitutes the instinctual and unreasonable part of the psyche which works under the impulses of the pleasure principle. It encloses the self's concealed desires, deep fears, and unfulfilled wishes. The id is also the storehouse of the libido, which is the source of the self's psychic energy and psychosexual desires, therefore, it is in constant search for instant satisfaction of the instinctual needs. The second part of the psyche, the ego, is the reasonable and rational part of the mind which operates according to the reality principle. With many of its activities still residing in the unconscious, the ego is considered to be the waking part of the mind whose job is to regulate the instinctual impulses of the id and to give them a nondestructive form once they are released. The third part of the psyche is the superego. It is that part of the 


\section{QALAAI ZANISTSCIENTIFIC JOURNAL \\ A Scientific Quarterly Refereed Journal Issued by Lebanese French University - Erbil, Kurdistan, Iraq \\ Vol. (6), No (1), Winter 2021 \\ ISSN 2518-6566 (Online) - ISSN 2518-6558 (Print)}

psyche which functions as an internal guard to make sure that the self's judgments are carried out morally in accordance to the socially acceptable rules. Whereas the id operates according to the pleasure principle, the superego works under the impact of the morality principle. It is left to the superego to protect society and the self from the damaging forces of the id. In its resemblance of society's moral sense of judgments and restrictions, the superego functions as the sensor that suppresses all the socially forbidden desires and instincts and pushes them back to the unconscious. It is also responsible for the sense of guilt and fear experienced by individuals in their daily experiences (2011, p. 127). Furthermore, Freud's theories of infantile sexuality and the psychosexual development of young kids into adult males and females, offer more insights into the formation of each of the three parts of the human psyche mentioned above. They also offer accounts of the nature of the unconscious thoughts these parts of the psyche have to deal with. These psychosexual theories in particular, have attracted the attention of the psychoanalytical feminists; since it was through these psychosexual processes that Freud arrived at a definition of masculinity and femininity, he further maintained that as a result of these processes, some parts of the human psyche (especially the superego), are developed to function differently in males and females.

Freud's theories of sexuality start with his definition of infancy as a period of extreme sexual experiences during which the id is formed (Dobie, 2015, p. 59). As maintained by Freud, it is not until children pass by different psychosexual stages (oral, anal, and phallic) that masculinity and femininity can be attributed to them. During the oral and anal stages, the infant's sexual pleasure is satisfied by parts of the mother's and the infant's own body. Later in the phallic stage, around the age of three or four, the child finds out about the genitals being a source of pleasure. It is at this stage that the so-called Oedipal crisis takes place. The child passes this stage by either succeeding to resolve his Oedipus complex or his failure to do so. At about the age of six, the display of overt sexuality is ceased by the child as he enters a period of latency that lasts until puberty after 


\section{QALAAI ZANISTSCIENTIFIC JOURNAL \\ A Scientific Quarterly Refereed Journal Issued by Lebanese French University - Erbil, Kurdistan, Iraq \\ Vol. (6), No (1), Winter 2021 \\ ISSN 2518-6566 (Online) - ISSN 2518-6558 (Print)}

which the young person retains his sexual impulses during the genital stage. The most critical stage in the psychosexual development according to Freud, is the moment of the Oedipus complex. Freud maintained that both boys and girls take their mother as the object of their desire during the pre-Oedipal stage, however, when they reach the phallic stage described above, with the interference of the father and his threat of castration, the boy learns to abandon his desire for his mother in his fear of being castrated by the father. Thus, the young boy passes by this stage quickly and his Oedipus complex is resolved along with internalizing a fear of castration that later creates a strong superego in him enabling him to have a sense of moral judgment and reason. The girls Oedipus complex, however, is dramatically different from the boy's since the girl does not have to yield to that fear of castration due to the fact that she is already castrated. Thus, Freud maintains that, the girl's Oedipus complex is never resolved but initiated by the threat of castration. Lacking the male organ, the girl acquires a feeling of hatred towards her mother and in her envy for the penis she shifts her object of desire from mother to father through whom she wishes to have a baby as a compensation for the male organ she longs for. Freud further argues that since the little girl does not have to fear castration as she doesn't have anything to lose, she does not internalize as strong a superego as the boy (Tong, 2014, pp.128-131).

Freud's remarks of penis envy and the weak superego in females has enraged most feminists. However, an analysis of the play under these certain Freudian concepts is crucial for understanding much of the later analysis based on other major contributions in the area of feminism and psychoanalysis discussed in the coming sections. The aim of this analysis is to show how a Freudian critic would view and interpret the struggles and the motives behind the actions of the female characters of the play.

The two central characters under discussion in this section are the characters of Fefu and Julia. They can be considered as the two characters that carry most of 
the feminist messages of the play. Carrying deep-rooted internal struggles, much of their unconscious thoughts and behaviours are shown throughout the play. In an attempt to understand Fefu's character in a Freudian approach, it is important to observe how she appears consecutively from the first part towards the end of the play. In part 1, the audience is introduced to her character and her life through three major revelations which are essential for this analysis.

First, as the play opens, the first voice to be heard is that of Fefu saying "my husband married me to have a constant reminder of how loathsome women are" (Fornes, 1978, p. 113). While her friends Cindy and Christina show feelings of discontent and shock at the remark Fefu is making of herself, she in turn, does not show any feelings of distress nor does she deny the fact that she is "loathsome". She even goes on to extend her judgment of herself to women in general. Then, in response to the question of how she finds being "loathsome" both an exciting idea and a revolting one, she continues:

FEFU: Hmm. - Have you ever turned a stone over in damp soil?

CHRISTINA: Ahm.

FEFU: And when you turn it there are worms crawling on it?

CHRISTINA: Ahm.

FEFU: were you revolted?

CHRISTINA: Yes.

FEFU: Were you fascinated?

CHRISTINA: I was.

FEFU: There you have it. You too are fascinated with revulsion.

CHRISTINA: Hmm. 


\section{QALAAI ZANISTSCIENTIFIC JOURNAL}

A Scientific Quarterly Refereed Journal Issued by Lebanese French University - Erbil, Kurdistan, Iraq

Vol. (6), No (1), Winter 2021

ISSN 2518-6566 (Online) - ISSN 2518-6558 (Print)

FEFU: You see, that which is exposed to the exterior ... is smooth and dry and clean. That which is not ... underneath, is slimy and filled with fungus and crawling with worms. It is another life that is parallel to the one we manifest. It's there. The way worms are underneath the stone. If you don't recognize it... (Whispering) it eats you. - That is my opinion. - Well, who is ready for lunch? (Fornes, 1978, p. 114)

It is this self-loathing and this internal conflict (between the conscious and unconscious mind) in Fefu that lies at the heart of her struggle and "the exposure of that dangerous underside...determines so much of the action of the play" (Hughes, 2000, p.2). By the comparison she makes between the "exterior" (Fornes, 1978, p. 114) part of the stone and what lies "underneath" (ibid.), she is metaphorically speaking of the conscious and unconscious parts of the human mind in general and of hers in particular. Fefu is well aware of the validity of the other life (the world of the unconscious) that is "parallel" (ibid.) to the life we "manifest" (ibid.) consciously, and she recognizes its existence too well because for her "if you don't recognize it...it eats you" (ibid.). The contrast between the unconscious and conscious thoughts are made much stronger and distinct by Fefu's ability to quickly shift the flow of the speech from important revelations of her inner psyche to asking about lunch to shift the attention of her friends, the audience and even herself away from the uttered unconscious thoughts.

The second major revelation about Fefu lies in her marriage and relationship with her husband. Soon after the previous dialogue, the audience is introduced to Fefu's husband Phillip. Hedoes not appear on stage but Fefu plays a game of shooting with him which she Fefu describes as the following:

FEFU: It's a game we play. I shoot and he falls. Whenever he hears the blast he falls. No matter where he is, he falls. One time he fell in a puddle of mud and his clothes were a mess. (She waves to Phillip and starts to go upstairs) He's all right. Look. 


\section{QALAAI ZANISTSCIENTIFIC JOURNAL}

A Scientific Quarterly Refereed Journal Issued by Lebanese French University - Erbil, Kurdistan, Iraq

Vol. (6), No (1), Winter 2021

ISSN 2518-6566 (Online) - ISSN 2518-6558 (Print)

(CHRISTINA looks out CINDY takes a deep breath)

CINDY: A drink?

CHRISTINA: Yes. (Fornes, 1978, p.115)

Once again, Fefu puts her female companions, Cindy and Christina, in a state of shock and leaves them perplexed to the degree that it requires Christina to immediately have a drink and this runs almost throughout the first part. This stresses the difference between Fefu and the other female characters such as Cindy and Christina. Conformist female characters like Christina refuse to confront or apprehend the truth of their situation and, would rather escape the truth with the help of drinking.

The third important key to understanding Fefu's character comes with her long speech about the differences between men and women. It can be regarded as a reflection of her unconscious thoughts in which once again, like her previous speech about the stone and the worms conflict between the unconscious thoughts spoken reflectively contrasts with her conscious act of plumbing which she mentions as soon as she finishes her speech:

FEFU: ... (FEFU goes to the doors she stands there briefly) I still like men better than women. - I envy them. I like being like a man. - They are well together. Women are not. (CHRISTINA offers CINDY her glass. CINDY pours bourbon in it) I'm driving you to alcoho...Women are restless with each other. They are like live wires...either chattering to keep themselves from making contact, or else, if they don't chatter, they avert their eyes... (Fornes, 1978, p. 118)

Looking back at the three revelations about Fefu's character mentioned above, from a Freudian perspective, it can be said that Fefu is under the effects of the castration complex and penis envy assigned by Freud.

Freud ties the nature of femininity to the castration complex to the degree that he describes the young girl's arrival at a 'positive' Oedipus complex, as argued 


\section{QALAAI ZANISTSCIENTIFIC JOURNAL \\ A Scientific Quarterly Refereed Journal Issued by Lebanese French University - Erbil, Kurdistan, Iraq \\ Vol. (6), No (1), Winter 2021 \\ ISSN 2518-6566 (Online) - ISSN 2518-6558 (Print)}

by Mitchell, as the initial step that places her on the right path of womanhood. This positive Oedipus complex is the state in which the little girl has successfully transferred her object of desire from her mother to her father. This is regarded as a positive Oedipus complex for the little girl since Freud describes this transference as the only normal path that turns the little girl into a woman. This shift in the object of desire, or the so called positive Oedipus complex for the girl happens only after the little girl has passed by the castration complex successfully. The castration complex for the little girl holds no threat as it only brings for the girl the realization that she is already castrated and lacks the male organ. Thus, with her realization of her castration of herself and her mother as well, the girl can be considered as having entered her feminine 'destiny'. This realization of castration is the phase in which the girl grows feelings of resentment towards her mother accusing her for failing to bring her to the world as a boy. It is this same phase that is characterized by penis-envy. The acceptance of castration is the cause of disappointment and feelings of inferiority due to the realization that there is a lack of the phallus. After the acknowledging of her castration and before a 'positive' entry into the Oedipus complex, the girl, having developed hostility to the mother due to her lack and with a demolished selflove is prone to maintaining an inferior and degrading attitude towards women and womanhood. She is also liable to refuse the idea of abandoning her active sexual status for replacing it with the passivity that comes with the transference of her sexual attention from mother to father (Mitchell, 2000, pp. 96-98).

Thus, from the above Freudian account of the psychical procedures that constitute femininity, Fefu can be regarded as unconsciously stuck in a state of castration complex in the first part of the play. This state in which she is refusing to enter into her stage of positive Oedipus complex since by entering it, she has to yield to the passive state designated for women by seeking to be the object of desire of the father; which in the future stands for seeking men's love. Hence, the inferiority, the self-loath Fefu showed at the beginning of the play that she extended to women in general, is equivalent to the resentment the little girl 


\section{QALAAI ZANISTSCIENTIFIC JOURNAL}

A Scientific Quarterly Refereed Journal Issued by Lebanese French University - Erbil, Kurdistan, Iraq

Vol. (6), No (1), Winter 2021

ISSN 2518-6566 (Online) - ISSN 2518-6558 (Print)

shows to her mother and women in general the moment the recognition of her castration occurs. Her admitting the fact that she envies men and likes being like men and thinking like them denotes her penis-envy. Lastly, the game she is involved in with her husband stands for her resistance to not enter the Oedipus complex because she knows that in a patriarchal society women:

FEFU: ... are always eager for the men to arrive. When they do, they can put themselves at rest, tranquilized and in a mild stupor. With the men they feel safe. The danger is gone. That's the closest they can be to feeling wholesome. Men are muscle that cover the raw nerve. They are the insulators. The danger is gone, but the price is the mind and the spirit .... High price. - I've never understood it. To give up the passion of friendship. - why? - What is feared? ... (Fornes, 1978, p. 118)

So, in the speech above, Fefu is seen to be questioning and criticizing women for having entered that stage of Oedipus complex she is refusing to enter. This stage according to Freud is the only path to femininity in which women have to stay forever, because, this transition from mother to father as the love object, is what prepares the little girl to be the object of desire of the male. Being the object of desire of the male is the only way for the female to fulfill her desire of the lack of the penis by having a child of her own in the future. Thus, as in Fefu's words, with the arrival of the men, women are "the closest...to feeling wholesome" (ibid.). Nonetheless, this transition and that entry into this state is not without "high price" (ibid), in fact "the price is the mind and the spirit" (ibid.) and this price is what Fefu is refusing to pay.

Fefu's questions in the above speech, additionally, can stand for Fornes' and most of the psychoanalytic feminists' concerns regarding this aspect of Freud's psychosexual theories. Most of the psychoanalytic feminists take Freud to be "genuinely puzzled by how femininity comes about: given the girl's prehistory of love and attachment to the mother, why would she switch allegiances to the father?" (Zakin, 2011, p. 5). Such questions raised by the psychoanalytic feminists, made Freud's theories of femininity inconvenient and incomplete 


\section{QALAAI ZANISTSCIENTIFIC JOURNAL \\ A Scientific Quarterly Refereed Journal Issued by Lebanese French University - Erbil, Kurdistan, Iraq \\ Vol. (6), No (1), Winter 2021 \\ ISSN 2518-6566 (Online) - ISSN 2518-6558 (Print)}

Later, in the second part of the play, Fefu's description of her intense pain to Emma denotes that she is on the way to her Oedipus complex, to the path destined for femininity which is characterized by passivity. Freud describes the girls' Oedipus complex being initiated by the threat of castration as a painful and difficult process for the young girl, as he states that "she makes the shift from mother love to father love only because she has to, and then with pain and protest" (Mitchell, 2000, p. 96). Fefu here is both in pain and in protest as she describes her pain as a "very strange [and a] very frightening" (Fornes, 1978, p. 123) kind of pain that is not "physical" (ibid.) and not even "sorrow" (ibid.). She is in protest because she does "not want to give in to it" (ibid.) but this pain has become a part of her since she admits "without it, life is a nightmare, and everything is distorted" (ibid.).

Lastly, in the third part of the play while confessing to Julia that she is in terrible need of her husband, Fefu can be said to have entered her Oedipus complex which is characterized by the love for man. Here, Fefu takes action, since entering Oedipus complex means surrendering to the fate predestined for all women which means residing in a state of passivity and a weaker superego incapable of proper judgment and reason. Fefu's action comes in the form of killing that passivity which is resembled in the character of Julia.

Julia's case, on the other hand, is different from Fefu's in that she, too, used to be like Fefu in her strength and individuation as in Fefu's words "she was afraid of nothing...she knew so much...she was so young and yet she knew so much" (Fornes, 1978, p. 119) but this has changed ever since she has been mysteriously injured by an accident. As the lone eyewitness to Julia's accident, Cindy recalls the accident for the first time after the passage of more than a year, which after a hunter aimed at a deer:

CINDY: He shot. Julia and the deer fell. The deer was dead ... dying. Julia was unconscious. She had convulsions ... like the deer. He died and she didn't. I screamed for help and the hunter came and examined Julia. he said, "She is not hurt." Julia's forehead was 


\section{QALAAI ZANISTSCIENTIFIC JOURNAL}

A Scientific Quarterly Refereed Journal Issued by Lebanese French University - Erbil, Kurdistan, Iraq

Vol. (6), No (1), Winter 2021

ISSN 2518-6566 (Online) - ISSN 2518-6558 (Print)

bleeding. He said, "It's a surface wound. I didn't hurt her." I know it wasn't he who hurt her. it was someone else. He went for help and Julia started talking. She was delirious. - Apparently there was a spinal nerve injury but the doctors are puzzled because it doesn't seem her spine was hurt when she fell. She hit her head and she suffered a concussion but that would not affect the spinal nerve. So there seems to be no reason for the paralysis. She blanks out and that is caused by the blow on the head. It's a scar in the brain. It's called the petit mal. (Fornes, 1978, p. 119)

This accident marks the point where Fefu and Julia part ways. Unlike Fefu, who resists entering the feminine destiny designated for all women, Julia has given up this fight and the above mysterious accident that defines her along with her paralysis, stand for the moment she accepts her castration and enters her positive Oedipus complex. In Cindy's recount of the accident, the moment the hunter shot the deer, Julia became delirious and at that moment she mentioned "that she was persecuted...that they tortured her...that they had tried her and that the shot was her execution...recanted because she wanted to live" (Fornes, 1978 , p. 119). Here, it becomes clear that with the accident which is equivalent to her moment of her accepting her castration, Julia "recanted" (ibid.) her previous position of being smart like Fefu, being active, and being able to stand on her feet as a female only to become another passive female character accepting the normal path all women had taken, apparently, this is the only way by which a woman is able to live in a patriarchal society.

Later on, Julia's hallucinations in the second part of the play provide a clearer image of the link between her accident, her paralysis, and Freud's castration complex and the consequences of penis envy. According to Freud, after a woman realizes that she has been castrated which he describes as a "wound to her narcissism" (Freud, 1925, p. 253, cited by Mitchell, 2000, p. 99), the woman "develops, like a scar, a sense of inferiority" (ibid.). Thus, after the accident, Julia frequently hallucinates about how at the moment the accident occurred, she 


\section{QALAAI ZANISTSCIENTIFIC JOURNAL}

A Scientific Quarterly Refereed Journal Issued by Lebanese French University - Erbil, Kurdistan, Iraq

Vol. (6), No (1), Winter 2021

ISSN 2518-6566 (Online) - ISSN 2518-6558 (Print)

was overcome with ideas of women being "anti-aesthetic" (Fornes, 1978, p. 127) and "evil" (ibid.). Julia's further describes the accident as follows:

JULIA: They clubbed me. They broke my head. They broke my will. They broke my hands. They tore my eyes out. They took my voice away...They clubbed me again, but my head did not fall off in pieces. That was because they were so good and they felt sorry for me. The judges. You didn't know the judges?... He said that I had to be punished because I was getting too smart. I'm not smart. I never was. Neither is Fefu smart. They are after her too. (Fornes, 1978, pp.126-127)

Julia here talks of the moment she was made to take the decision of abandoning her previous smart self and enter that state of being crippled to remain as a helpless woman contrary to the previous strong Julia Fefu mentioned earlier. She also mentions how the mysterious "judges" (ibid.) who crippled her and made her "repent" (ibid.), are after Fefu too. Julia's speech denotes that the normal path designated by Freud for all women, which is characterized by passivity and a weak superego, is the path that awaits all women. They have to enter it sooner or later. There is no place for women like Julia and Fefu who are smart and who question the reality. What is interesting in Julia's hallucinations and her part of recalling the incident is her mentioning of the word "judges" (Fornes, 1978, p. 126). By putting certain mysterious judges in the position of being in charge of Julia's accident along with being the main agents that make up her hallucinations, Fornes makes the reader question and reconsider the relation between the psychical world and its links to the social reality. Whether the judges are part of the psychosexual drama that makeup each individual or they are mere resemblances of outer forces leaving their impact on the individual, especially the woman, is one of such questions raised by Fornes.

From the above analysis of the situation of the female characters of Fefu and Her Friends through Freud's theories of Femininity, it becomes clear to what extent Freud's theories depend on anatomy and inner procedures regardless of the 


\section{QALAAI ZANISTSCIENTIFIC JOURNAL \\ A Scientific Quarterly Refereed Journal Issued by Lebanese French University - Erbil, Kurdistan, Iraq \\ Vol. (6), No (1), Winter 2021 \\ ISSN 2518-6566 (Online) - ISSN 2518-6558 (Print)}

social forces that help in shaping individuals. Viewing the dilemmas of the female characters in the light of Freud's theories, gives the impression that all what women are facing is due to the fact that they are simply women and this is how their psyche performs. By assigning femininity to penis envy, as argued by Bowlby, Freud seems to be presenting "femininity [as] the place where no man, -male or female- wants to be" (2002, p. 48). It is against these views that feminists turned against Freud's assumptions and tried to explore different areas through which the effect of the patriarchal society becomes evident in the psyche of women.

\section{The Symbolic Order, Language, and Female Subjectivity}

While much of the hostile criticism addressed to Freud and his theories were based on his antifeminist and misogynist ideas, it was against the universality of his claims that most of the debates took place. Increased controversy arose in the face of the validity of the Oedipal model belonging to all times and all places. Therefore, the critics interested in psychoanalysis, and especially feminism, shifted their attention from Freud to Jacques Lacan mainly because his theories avert the rigid developmental structure designated by Freud. Alternatively, Lacan provides a 'relational' pattern that makes some place for difference (Bertens, 2008, pp. 125-126).

Lacan's emphasis on the Symbolic order, language, the law of the father, and sexual difference is what mostly attracted the feminist critics dealing with psychoanalysis. According to Vice:

\footnotetext{
Lacan's great innovation was to emphasise the simultaneous acquisition of language and concept of one's self at the moment of the Oedipal crisis. The child is catapulted at once into the symbolic world of language, law and sexual difference. (Vice, 1998, p. 168)
}

Thus, as soon as the child leaves the imaginary state and enters the symbolic stage leaving all the ties that once connected him with his mother in the former 


\section{QALAAI ZANISTSCIENTIFIC JOURNAL \\ A Scientific Quarterly Refereed Journal Issued by Lebanese French University - Erbil, Kurdistan, Iraq \\ Vol. (6), No (1), Winter 2021 \\ ISSN 2518-6566 (Online) - ISSN 2518-6558 (Print)}

stage he has to accept the language and the social and cultural systems that mark his environment. This, according to Lacan is achieved via the name of the father and the signifier phallus which signifies that patriarchal authority (Bertens, 2008, p. 126). Hereafter, the concern of feminist approaches rises with regard to Lacan's view about the nature of the symbolic.

What forms the debate about Lacan's theory amongst the feminist literary critics as according to Brennan is "that Lacan's symbolic makes patriarchy seem inevitable [and its] patriarchal nature relies on the interlocking functions of the symbolic father ... and the notorious phallus" $(2002$, p. 3). What Lacan says about the phallus is that it stands as an emblem for each of first; the paternal power, second; the sexual desire the father carries for the mother and third; the state of unification with the mother that only the father can access (Stone, 2016, p. 878). These claims make it likely that there is a greater chance for the son to identify itself with the phallus in aspiring to be one day a powerful figure like the father owning all the above qualities that belong to the phallus. Although Lacan insists that every individual lacks the phallus in a way, his distinguishing between a 'seeming to be' and a 'seeming to have' that one is not, seems to stand for females and males in the positions of being the object of desire in the case of the former to possessing the object of desire in the case of the latter (Zakin, 2016, p.14).

Starting from the 1970s, a number of French feminists came to challenge the way Lacan's symbolic order deprives women from subjectivity leaving them to stay entrapped in the position of the other. Among the most notable French feminists of this era are Helene Cixous (1937- ), Julia Kristiva (1941- ), and Luce Irigaray (1930- ), whose ideas and arguments are applicable to the play. What brings these three feminists together is their preoccupation with language, as argued by Tyson, because for them language is one of the grounds upon which most of women's psychological suppressions take place. Language is also the factor through which the concept of sexual difference is defined. Patriarchy has 
defined these differences as inherent and essential in distinguishing women from men (Tyson, 2015, p. 95).

The French feminists here adopt an interdisciplinary approach in dealing with the issues of women, integrating the structuralist disciplines with psychoanalysis and feminism. An early significant essay relating the concept of binary oppositions to feminism is Helene Cixous' sorties published in 1975 in which she proposes a list containing a set of binary oppositions asking 'where is she?':

Activity/passivity

Sun/Moon

Culture/Nature

Day/Night

Father/Mother

Head/Emotions

Intelligible/Sensitive

Logos/Pathos (Cixous and Clement, 1986, P. 63)

According to Cixous, in the binary oppositions that form patriarchal discourse and language, femininity is constantly allied with powerlessness (Ehlers, 2016, p. 357). She further argues that the male/female opposition exists prevalently in all kinds of oppositions making them central to Western culture (Bertens, 2008, p. 130). This is also one of the reasons why inside the patriarchal framework of thinking it is the norm for women to be passive as compared to men who are believed to be active following the assumption that they are both born in this manner and that this is the way by which the sexes are differentiated. Consequently, this passivity acts as one of the natural marks of womanhood taking women down the road of submission to men who are the natural leaders. This is because for Cixous, "traditionally, the question of sexual difference is treated by coupling it with the opposition activity/passivity" (Cixous, 1987, p. 192 cited by Tyson, 2015, p. 96).

For Cixous, the proposed solution for women to overcome such patriarchal modes of thought with its root in language and the nature of the symbolic order, is to abandon the idea of aspiring to be part of the patriarchal power. By asking 


\section{QALAAI ZANISTSCIENTIFIC JOURNAL \\ A Scientific Quarterly Refereed Journal Issued by Lebanese French University - Erbil, Kurdistan, Iraq \\ Vol. (6), No (1), Winter 2021 \\ ISSN 2518-6566 (Online) - ISSN 2518-6558 (Print)}

for equal rights with men inside the patriarchal system, Cixous maintains, women ask for an admission into the sociopolitical system of that power. Hence, even if this is achieved, it does not in fact propel any changes to the system but it rather trains women how to think like patriarchal men by being inside its framework. As an alternative, she claims that women should take themselves as the source of power and energy because women are the source of life. Based on this, women need to invent a new language that challenges and shackles the patriarchy's binary oppositions through its flexibility and freely communicative nature (Tyson, 2015, p. 96). This mode of language is best described by ecriture feminine which means feminine writing. Thus for Cixous "Women must write through their bodies, they must invent the impregnable language that will wreck partitions, classes, and rhetorics, regulations and codes" (Marks and de Courtivron, 1981, p. 256).

Taking into consideration Cixous' assumptions, much of the hallucinations of Julia in the second part of the play come into light. Being caught inside her unconscious mind, Julia's hallucinations give a precise example of how these patriarchal binary oppositions affect women and engrave in them that sense of passivity and inferiority to carry them for life:

Everything on earth is for the human being, which is the man. To nourish him. - there are evil things on earth, and noxious things. Evil and noxious things are on earth for the man also. For him to fight with, and conquer and turn its evil into good. So that it too can nourish him. - there are Evil Plants, Evil Animals, Evil Minerals, and Women are Evil...God gave man no other mate but woman. The oxen is good but it is not a mate for man. The mate for man is woman and that is the cross man must bear. - Man is not spiritually sexual... His sexuality is physical...Women's spirit is sexual. (Fornes, 1978, p. 127)

From that speech, how Julia uses the binary oppositions of man/woman, good/evil, spiritual/sexual, spiritual/physical denotes the degree to which these 
differences between men and women become psychologically internalized into women's unconscious thoughts. What is most important is that Julia has to say these words in a form of a prayer which symbolizes the fact that these thoughts come in a way that are imposed as an ideology by the male-dominated system represented in the form of the 'judges' Julia refers to in her hallucinations.

Cixou's ecriture feminine, however, does not provide an adequate answer for Julia's well-being. Julia has already become paralyzed and "crippled" (Fornes, 1978, p. 127) by the power of the "judges" (ibid.) dwelling inside her unconscious who always remind her of women's "stinking parts of the body" (ibid.) with images of women being "anti-aesthetic"(ibid.) and their "entrails...heavier than anything on earth"(ibid.). With these images running constantly through the mind, it is impossible for a woman to embrace her body and indicate it as a source of power and life as Cixous maintains so that she can create a language through it. Many feminists, therefore, avoid essentialist views in their claims specifically when "such 'essentialism' is difficult to square with a feminism which emphasizes femininity as a social construct, not a given 'entity which is somehow just mysteriously 'there'”' (Barry, 2009, p. 123).

To avoid such charges of essentialism, the French Feminist Julia Kristiva, poses different views. According to Kristeva, who is also interested in the role of language and subjectivity, ecriture feminine is not the efficient answer to subordinations of women and based on language. She argues that, theories based on essentialism which infer biological, essential, and innate characteristics on women, fail to account for the diversity of women and leave them under the charges such as being naturally obedient, passive, or emotional. Kristeva refutes any definitions for the feminine due to believing in its diversity. What is to be known for a fact about femininity, she argues, is that it is marginalized and oppressed in a way equivalent to that of the working class. Kristeva further demolishes biological differences and replaces them with social differences because the oppression of women is based on the social meaning assigned to sexual difference (Tyson, 2015, p. 98). 
Kristeva also maintains that identity is by no means a fixed essence nor is subjectivity a "truth". Rather, she argues, the self is established within the realm of language and is under the influence of both the Symbolic Order and the unconscious; a theory which she calls "the subject in process" (Kristeva, 1986, Cited by Ehlers, 2016, p. 357). She assigns the terms the symbolic and the semiotic to give access to two dimensions of language. In an essay entitled The System and The Speaking Subject she links the symbolic aspect with order, fathers, authority, power and control, and defines it as the aspect in which words function meaningfully. On the contrary, she finds that what characterizes the semiotic aspect is far from order and logic for it is that aspect of language which contains elements of body language, intonation and rhythm, and which also contains elements of the unconscious such as 'condensation, slippage, displacement'. Thus, by the means of the semiotic language, one is enabled to retain access to the earliest states of the imaginary stage, of that state of feeling wholesome with the mother and a reconnection with the instinctual drives. Since these connections with the earlier states of the imaginary order are ruptured by the individual's entrance into the symbolic order, Kristeva maintains that the semiotic part of language escapes that patriarchal authority of the symbolic order, and by escaping it, it takes with it whatever patriarchy cannot control and suppresses it in the unconscious. By maintaining access to that semiotic part of the unconscious, women will be able to relate in new ways to language and free themselves of the thought restrictions and sensors patriarchy has prescribed for them. This, in turn, is achieved by preoccupying oneself with areas such as art and literature that work as vehicles to that semiotic aspect (Barry, 2009, p. 123; Tyson, 2015, p. 99).

Of all the female characters in Fefu and Her Friends, it is worth mentioning that Emma appears to be the most cheerful one and of a stronger presence. She appears to possess more inner peace than almost all of the other female characters. Based on Kristeva's views, this strength and cheerfulness in Emma's character can be due to her access to that semiotic order through which she 
becomes able to shift her attention away from the patriarchal chains that confine the other women in one way or another. In part one, while the audience is preoccupied with Cindy and Christina's recall of Julia's accident, that gloomy atmosphere is temporarily cleared by the arrival of Emma whose actions and speeches create a sense of boisterousness from the first moment of her joining the other women:

FEFU: (off-stage) Emma! What is that you're wearing. You look marvelous.

EMMA: (off-stage) I got it in Turkey.

(CIINDY goes out to greet [Paula and Sue]. JULIA enters. She wheels herself to the downstage area)

FEFU: I'll be right down. (Short pause) Hey, my toilet works.

EMMA: That's marvelous Stephan. Mine does too.

FEFU: Don't be funny.

EMMA: Come down. (FEFU enters)

FEFU: They're here. (She goes to the foyer as EMMA, SUE and PAULA enter. EMMA and FEFU embrace) How are you, my child?

EMMA: Good ... good ... good ... (Still embracing FEFU, EMMA sees JULIA) Julia! (She runs to Julia and sits on her lap)

FEFU: Emma!

JULIA: It's all right.

EMMA: Take me for a ride. (JULIA wheels the chair. EMMA waves as they ride) $\mathrm{Hi}$, Cindy, Paula, Sue, Fefu. (Fornes, 1978, p. 119) 


\section{QALAAI ZANISTSCIENTIFIC JOURNAL \\ A Scientific Quarterly Refereed Journal Issued by Lebanese French University - Erbil, Kurdistan, Iraq \\ Vol. (6), No (1), Winter 2021 \\ ISSN 2518-6566 (Online) - ISSN 2518-6558 (Print)}

In the second part of the play Emma is shown in the lawn with Fefu, where she recites a sonnet by Shakespeare after listening to Fefu talking about her inner pain. It is also Emma who takes the matter of the rehearsal in her hands encouraging the other women when they seem to be at loss as to what to wear, and how to move and act. She reassures Paula that "She'll work with [her] on it" (Fornes, 1978, p. 132) while it is supposedly her turn on stage giving her directions as how to "Breathe ... in ... And bow" (ibid.). Her speech, nevertheless, marks the most important part of their rehearsal in which she recites a passage from the prologue to "The Science of Educational Dramatics" by Emma Sheridan Fry. She becomes so in love with the speech and the rehearsal that she throws herself on the couch as soon as she finishes exclaiming "Oh, it's so beautiful" (ibid., p. 133). It is these preoccupations with childlike behaviors, and this turning into the world of literature and art that account for Emma's spontaneous and somehow joyful attitudes and this is also what Kristeva meant by an access to the semiotic.

Another major contribution to the field of psychoanalysis and feminism is considered to be that of the French feminist and philosopher Luce Irigarary who also deals with the interrelatedness of language to the symbolic order. Through her philosophical approach to the issue of sexual difference, Irigaray suggests that "women's exploitation is based upon sexual difference; its solution will only come about through sexual difference" (1993a, p. 12).

Irigaray's theories and ideas stem from the way Western culture has deprived women of the possibility of being independent subjects acting, speaking, and thinking like women, from the psychoanalytical views of Sigmund Freud and the phallocentric views of Lacan. Irigaray states that, "any theory of the 'subject' will have always been appropriated as "masculine'" (Irigaray, 1985, p. 133, cited by Stone, 2016, p. 881). The way the feminine has always been defined, argues Irigiraray, is through the perspective that they are the negative or the lower version of the masculine. They are the object opposite to the masculine subject always referred to in terms of their relation to the masculine (Stone, 2016, p. 


\section{QALAAI ZANISTSCIENTIFIC JOURNAL \\ A Scientific Quarterly Refereed Journal Issued by Lebanese French University - Erbil, Kurdistan, Iraq \\ Vol. (6), No (1), Winter 2021 \\ ISSN 2518-6566 (Online) - ISSN 2518-6558 (Print)}

881). Irigaray refers back to the views of Freud as to the lack of sexual difference between the sexes. Freud maintained that the male is the origin of the sexual subject. He referred to women only in the form of being mothers. While little girls are assumed to diverge from little boys at some point as they stop to be the little men they once used to be in their childhood, argues Irigaray, the position they take is only of a pleasing visual object. An object acting as a mirror reflecting men's desires providing them with a positive self-image and an adoring reflection. As a function common to all women, they should be able to nurture and nourish men's desires and identities letting themselves come next (Zakin, 2011, p. 17).

Since being female is not verified as an identity that is subjective in its own right, an identity just standing there as the opposite side to the male positive identity, women are left with little choice in search for their subjectivity. Women who aspire to have a voice, an independent identity and a subjectivity of their own, have one way by which they can achieve their goal. That would be placing themselves in the position of the non-feminine or a sex-neutral speaker (Stone, 2016, p. 881). To that regard, Irigaray claims that:

There is, in an initial phase, perhaps only one "path," the one historically assigned to the feminine: that of mimicry. One must assume the feminine role deliberately. Which means already to convert a form of subordination into an affirmation, and thus to begin to thwart it. Whereas a direct feminine challenge to this condition means demanding to speak as a (masculine) "subject," that is, it means to postulate a relation to the intelligible that would maintain sexual difference. (Irigaray, 2004, p. 795)

Irigaray's insistence on the role of language and discourse in changing the condition of women is expressed in her notion of womanspeak. She invents the imagery of "two lips", oral and genital to stand for both of women's language and their desires as opposed to the symbol of the phallus invented by Lacan. 


\section{QALAAI ZANISTSCIENTIFIC JOURNAL \\ A Scientific Quarterly Refereed Journal Issued by Lebanese French University - Erbil, Kurdistan, Iraq \\ Vol. (6), No (1), Winter 2021 \\ ISSN 2518-6566 (Online) - ISSN 2518-6558 (Print)}

Irigaray's preoccupation with language comes with her belief that the different kinds of female subordinations take place psychologically through the medium of language in a world where all meaning is assigned to the patriarchal language. This puts women in a state of passivity in which they only imitate previously uttered ideas rather than being active originators of their own voice. Acting as mirrors of men's desires, women are believed to be deprived of their own thoughts, ideas, and desires assumedly always wanting what men want. Thus, women are bound to either, follow these assumptions and accept that inferior role patriarchy has designated for them, or to keep silent (Tyson, 2015, p. 97).

This is true to most of the female characters in the play; First, Julia is being tortured by her own unconscious whether as a result of her own illness or as the effect of patriarchy on her inner psyche, either ways she is doomed to keep quiet about it because any spoken thought, idea, or desire that does not fit the patriarchal system put her at risk of being persecute. This could be one of the reasons that make her situation worse because as she finally states it in the third part of the play, she needs to be around others who hallucinate like her too, perhaps in the hope that even if it is through their hallucinations they might come to talk their heart out to each other without being watched by the judges and the patriarchal guards.

Cindy, also, is destined to stay silent. About her own ended relationship with her partner, about Julia's hallucinations that she had overheard as the lone witness of her accident, and most prominently, about her own inner dilemmas that are repressed to the level that they only find shelter in her dreams where they are not under the conscious threats of patriarchy. In part two, Cindy recalls the dream she has had the night before that expresses much of her silent unspoken thoughts (about her partner Mike, about the abuse she is experiencing under the hands of the male, about her inability to speak, and about her self-esteem). What is worth mentioning is that even in the dream when at last she speaks up, she is struggling with expressing herself freely: 


\section{QALAAI ZANISTSCIENTIFIC JOURNAL}

A Scientific Quarterly Refereed Journal Issued by Lebanese French University - Erbil, Kurdistan, Iraq

Vol. (6), No (1), Winter 2021

ISSN 2518-6566 (Online) - ISSN 2518-6558 (Print)

CINDY: I was at a dance. And there was a young doctor I had seen in connection with my health. We all danced in a circle and he identified himself and said that he had spoken to Mike about me, but that it was all right, that he had put it so it was all right. I was puzzled as to why Mike would mind and why he had spoken to him. (Fornes, 1978, pp. 125-126)

Notably, it is an image of authority, a male doctor, who solves Cindy's problems with her partner Mike. He is the patriarchal figure that steps in to solve her problems for her. Cindy goes on in her recount of her dream:

Then, suddenly everybody sat down on the floor and pretending they were having singing lessons and one person was practicing Italian. The singing professor was being tested by two secret policemen. They were having him correct the voice of someone they had brought. He apparently didn't know how to do it. Then, one of the policemen put his hands on his vocal cords and kicked him out the door. Then he grabbed me and felt my throat from behind with his thumbs while he rubbed my nipples with his pinkies. (Fornes, 1978, pp. 125-126)

This above part of the dream clearly shows Cindy's vulnerability and helplessness as an object of sexual desire, viciously attacked by another image of male authority. In the next part of Cindy's recount another image of male authority is added to those of the policeman and the doctor, that of the "young man":

Then, [the policeman] pushed me out the door. Then, the young doctor started cursing me. His mouth moved like the mouth of a horse. I was on an upper level with a railing and I said to him, "Stop and listen to me." I said it so strongly that he stopped. Everybody turned to me in admiration because I had made him stop. Then, I said to him, "Restrain yourself." I wanted to say respect me. I wasn't sure whether the words coming out of my 


\section{QALAAI ZANISTSCIENTIFIC JOURNAL \\ A Scientific Quarterly Refereed Journal Issued by Lebanese French University - Erbil, Kurdistan, Iraq \\ Vol. (6), No (1), Winter 2021 \\ ISSN 2518-6566 (Online) - ISSN 2518-6558 (Print)}

mouth were what I wanted to say. I turned back to ask my sister. The young man was bending over and trembling with mad rage. Another man told me to run before the young man tried to kill me. Meg and I ran downstairs. She asked me if I wanted to go to her place. We grabbed a taxi, but before the taxi got enough speed he came out and ran to the taxi and was on the verge of opening the door when I woke up. (Fornes, 1978, pp. 125-126)

From the disparity of the subjects making up Cindy's dream, it becomes obvious how much of unuttered thoughts, feelings, and desires she has suppressed throughout her life this is one of the reasons why Irigaray attempted to put an end to women's psychological sufferings based on language.

Irigaray also claimed for a sexual difference that is not based on binary oppositions, a genuine sexual difference that can be attained through the creation of a symbolic order that makes place for that difference. A symbolic order that embodies both; first, sexual difference as it is known as the hierarchical differences between men and women as males and females, and, second, a sexual difference that acknowledges the psychical differences between men and women as being different in their desires, fantasies, and inner lives. This difference is a difference that works both on the psychical as well as the bodily level (Stone, 2016, p. 883). In terms with her philosophy of sexual difference, comes the idea of a politics of sexual difference. The aim would be as Braidotti describes it "how to struggle for the achievement of equality in the assertion of difference" (2002, p. 91). As Irigaray believes that when feminists ask for equality, the equality sought is with men, this mindset in itself makes men and the patriarchy to remain in the stereotypical position they are already occupying. In asking for equality with men, women would be obligated to mold themselves on men in an attempt to submit to the already established meanings based on the masculine. Thus, in Irigaray's view, the struggle for equality will only renew the old system of taking the masculine as the only one ideal (Stone, 2016, p. 885). 
From the politics of sexual difference, the idea of the differences among women, their relationship to each other and the role of the mother comes into being. In her book "An Ethics of Sexual Difference", Irigaray maintains that women's relationship to each other starts from the love they have for the self and the position of the mother which affects their psyches. "The love of self" argues Irigaray, "is very hard to establish" this because women have first experienced this love in their unification with their mothers and this unification consequently had to be abandoned for the love of the father as Freud maintains. This leads to the convention that love for the mother can be experienced only through "substitution" which is unconsciously marked by displacement and despise. Thus, argues Irigaray the love among women is based on competition, on who is to occupy the space of the mother as this position is the ultimate position for women acknowledged by the patriarchal culture. This competition of the place of the mother goes on to extend to the relationship or love between women as sisters or friends who compete on who is going to win the place of the "mother of mothers" and to win the attraction of "son for mother, mother for son". So, the love among women based on matters of rivalry such as that for "real mother" and the competition to win "the desire of man: of father, son, brother" leads women to being in a state of "quantitative estimates" among each other. This means that women tend to always view each other based on how much do they look like each other, how much they differ from each other and to what extent they possess more or less qualities than the other. This consequently puts women in a state of continuous judgment to be extended by women onto other women. This attitude of competence and rivalry holds women in a stagnant condition as no woman wants the other to do better than her, and this ultimately prevents any woman "from standing out from an undifferentiated grouping". Thus concludes Irigaray:

Without realizing it, or willing it, in most cases, women constitute the most terrible instrument of their own oppression: they destroy anything that emerges from their undifferentiated condition and thus become 


\section{QALAAI ZANISTSCIENTIFIC JOURNAL \\ A Scientific Quarterly Refereed Journal Issued by Lebanese French University - Erbil, Kurdistan, Iraq \\ Vol. (6), No (1), Winter 2021 \\ ISSN 2518-6566 (Online) - ISSN 2518-6558 (Print)}

agents of their own annihilation, their reduction to a sameness that is not their own. A kind of magma, of "night in which all the cats are gray," from which man, or humanity, extracts for free what he needs for food, lodging, and survival. (1993b, pp. 102-104)

With this view of Irigaray, one can provide at least one answer for the ending of Fefu and Her Friends, for the ending is so intense, so obscure and absurd that no one particular answer seems to act as the right answer for it. Nevertheless, it can be concluded that it is this sense of difference among women that is lacking. It is this entanglement inside an "undifferentiated group" mentioned by Irigaray that is lacking among the women. Although a feminist, Fefu does not want Julia to be different from her nor does she allow herself to become like her when towards the end of the play she tells Julia "you are contagious. I'm going mad too." (Fornes, 1978, p. 139). In the midst of this conversation Fefu grabs the gun, goes outside and Julia becomes injured.

Lastly, it can be said that the Contribution of the French psychoanalytical feminists building their assumptions on the theories of Lacan and at times Freud, opened up new arguments among other feminists especially the AngloAmericans who provide less philosophical views on issues of the difference between men and women, the mother/daughter relationship in the form of object/relation theory and whole new debates on the mechanics of gendered identity and gender roles.

\section{Gender Identity and Codes of masculinity and Femininity}

The modern concept of gender, which is considered to be the factor that differentiates biological sex from social sex, has been a topic of much recent debate and controversy. First and foremost, it is worth mentioning that the term gender has neither been among the focal points of study within feminism nor has it been developed within the movement itself, yet it gained much of its popularity from the contributions of the feminist movement of the second half of the twentieth century. Moreover, the use of "gender" has functioned as the 
means by which feminist studies could gain access into scientific disciplines that had previously questioned the subjectivity and hostility of feminist studies. The term gender as a socially and culturally constructive entity has occupied a wide place for investigation inside these disciplines. By demonstrating that the biological and the social belonged to different fields, and that social discriminations based on sex should not be viewed as "natural", what feminists maintained was that power inequalities between men and women were not a result of anatomical differences between the sexes. With this view in mind, gender was classified as the cultural equivalent of sexual difference that offered new grounds for the examination and the reduction of the inequalities between the sexes that were socially constructed (Vigoya, 2016, pp. 852-856).

Among the significant branches of psychoanalytical feminism that took into its concern issues of gender and identity, is the Anglo-American feminist object relation theory. The proponents of that area mainly investigated the way gendered identity was engraved in the psyche as an outcome of the relationship between parents and children (Ehlers, 2016, p. 352).

The American psychoanalysts on their part, were seeking to put an end to the shortcomings of Freudian psychoanalysis that resulted in the devaluation of femininity with their basis primarily been found in Freud's entire theory. As suggested by Schafer Freud's metapsychology with its biological basis, presupposed a dependence on drives on instincts to the degree that it constituted a narrative of psychological development that provided little space for factors such as cultural or interpersonal relationships (Schafer 1974, cited by Buhle, 1998, p. 244).

With their insights on issues of gender, the American psychoanalysts broke completely with Freud as the term in itself was alien to Freud. Psychoanalysts now believed that the development of gender is mostly dependent on experiential as opposed to the inherent and instinctual factors. This group of psychoanalysts, mainly the post-Freudians, shared the view that gender arises 


\section{QALAAI ZANISTSCIENTIFIC JOURNAL \\ A Scientific Quarterly Refereed Journal Issued by Lebanese French University - Erbil, Kurdistan, Iraq \\ Vol. (6), No (1), Winter 2021 \\ ISSN 2518-6566 (Online) - ISSN 2518-6558 (Print)}

within a relationship, most prominently a relationship crucial to the infant in his early stages of life (Buhle, 1998, p. 245).

In her interdisciplinary study bringing together psychoanalysis, sociological theory, and feminist theory, Nancy Chodorow argues that the early family experiences of boys and girls are the major cause behind psychological gender differences. Chodorow bases her argument on the fact that infants are narcissistic as when they start life and through their early years they depend totally on the mother. Assuming the labor division in most families, the infant's dependent needs are almost exclusively met by the mother. Thus, the infant's narcissistic self supposes that the mother has no other interests rather than the child. This early strong attachment to the mother, Chodorow maintains, causes difference in the developmental progressions for boys and girls. Thus, in the case of boys, they should put an end to that intense attachment to the mother in order to develop a masculine identity. Thus, since masculine identity is built on the exclusion of feminine maternal attachment, masculine identity can be characterized by independence and individuation mixed with the elimination and devaluation of the feminine. In the case of the girls, however, they don't need to break their attachment with the mother so as to develop a feminine identity they indeed grow stronger bond with the mother. Hence, girls' identity is not built on individuation; their identity is defined by being relational (Hyde and Oliver, 2000, p. 58).

In his analysis of the psychosexual developmental processes of little boys and girls, Freud regarded women as being less capable of reason and judgment as a result of tying the process of the super ego formation to castration anxiety. Being naturally deprived of the capacity to resolve their Oedipus complex, the superego in girls is expectedly of lesser capacity towards becoming independent and neutral as compared to that of men. Thus, as Freud's theory suggests, women's judgments is characterized by being based on feelings and emotions. Challenging those Freudian assumptions of femininity, Chodorow states that the sex differences peculiar to the early experiences of identity formation "does not 


\section{QALAAI ZANISTSCIENTIFIC JOURNAL}

A Scientific Quarterly Refereed Journal Issued by Lebanese French University - Erbil, Kurdistan, Iraq

Vol. (6), No (1), Winter 2021

ISSN 2518-6566 (Online) - ISSN 2518-6558 (Print)

mean that women have 'weaker' ego boundaries than men or are more prone to psychosis" rather, the situation is that "girls emerge from this period with a basis for 'empathy' built into their primary definition of self in a way that boys do not." Thus, Chodorow provides a substitute of the description of female psychology that stands as a positive account opposed to the negative one proposed by Freud that she further elaborates as follows:

Girls emerge with a stronger basis for experiencing another's needs or feeling as one's own (or of thinking that one is so experiencing another's needs and feelings). Furthermore, girls do not define themselves in terms of the denial of preoedipal relational modes to the same extent as do boys. Therefore, regression to these modes tends not to feel as much a basic threat to their ego. From very early, then, because they are parented by a person of the same gender ... girls come to experience themselves as less differentiated than boys, as more continuous with and related to the external object-world, and as differently oriented to their inner object-world as well" (Chodorow, 1978, p. 167 , cited by Gilligan, 2003, p. 8)

Hence, one can find answers for the various kinds of problems that occur within a relationship between men and women, why does the female always strives after being loved, cared for, and feeling unified with their significant other while the male seems to be in good terms on his own? The answer here lies in the fact that the case is so not because of the common patriarchal view that women are naturally submissive, weak, and dependent on others but as Gilligan states:

Since masculinity is defined through separation while femininity is defined through attachment, male gender identity is threatened by intimacy while female gender identity is threatened by separation. Thus males tend to have difficulty with relationships, while females tend to have problems with individuation. (Gilligan, 2003, p. 8) 


\section{QALAAI ZANISTSCIENTIFIC JOURNAL \\ A Scientific Quarterly Refereed Journal Issued by Lebanese French University - Erbil, Kurdistan, Iraq \\ Vol. (6), No (1), Winter 2021 \\ ISSN 2518-6566 (Online) - ISSN 2518-6558 (Print)}

Also, one of the reasons that causes women's alienation from others as Kahn mentions "because a woman is the first significant other through whom both girls and boys realize subjectivity, women in general become charged with the ambivalence of fear and desire which is the in-evitable byproduct of that process" (2004, p. 827). Seeing the woman as a subject of his desire yet his fears, the man cannot help but keep distance from her.

Part of Fefu's internal struggle lies in this aspect of her relationship with her husband. While Fefu suffers from his absence, Phillip never seems to be there. Fefu relieves herself and is contented by the attachment she gets with her husband through this strange game of shooting no matter how risky it seems to be. She longs for his presence and the game fulfills that for her. However, at last she admits that she is in constant pain, a kind of pain that causes an internal conflict in her and that which she runs away from by showing herself as being strong and indulged in a game of love with her husband. Her pain is intensified while towards the end of the play she desperately confesses to Julia:

FEFU: Phillip can't stand me. He's left. His body is here but the rest is gone. I exhaust him. I torment him and I torment myself. (She holds JULIA) I need him, Julia. I need his touch. I need his kiss. I need the person he is. I can't give him up. I need to be everything to him. I try to leave him alone but I can't. I try to swallow my feelings but I can't. They choke me. I want to rest, Julia. How does a person rest. I want to put my mind at rest. I am frightened and I'm overbearing. - I look into your eyes and I know what you see. (JULIA cries) I'm not giving in. (Fornes, 1978, p. 140)

Hereby, in an attempt to put an end to such rigid gendered fixations that predetermine women's fate in a relationship to be the abandoned regardless of the nature of the relationship itself, Chodorw and the object relation theorists argue that that since this process of identity formation is social, the solution and a change in these characteristics of male and female identity could be changed 


\section{QALAAI ZANISTSCIENTIFIC JOURNAL \\ A Scientific Quarterly Refereed Journal Issued by Lebanese French University - Erbil, Kurdistan, Iraq \\ Vol. (6), No (1), Winter 2021 \\ ISSN 2518-6566 (Online) - ISSN 2518-6558 (Print)}

through shared parenting where "altered conditions - such as greater involvement from the father - could transform gender norms, the sexual division of labor, and, theoretically, the contours of gendered identity" (Ehlers, 352). Positing a different view towards gendered identity, and gender roles, Judith Butler introduces new insights to the nature of gender formation and the way it works. In her book Gender Trouble: Feminism and the Subversion of Identity, she argues that gendered identity depends entirely on social factors as opposed to reflecting any inner truth or stability. Gender for Butler is defined by performativity which she further elaborates as follows:

The view that gender is performative sought to show that what we take to be an internal essence of gender is manufactured through a sustained sets of acts, positioned through the gendered stylization of the body. In this way, it showed that what we take to be an "internal" feature of ourselves is one that we anticipate and produce through certain bodily acts. (1999, p. XV)

Thus, for Butler, it is the act of behaving and acting in accordance to society's codes of masculinity and femininity that determines gendered identity. It is through the continuous acquired actions and performances individuals through which gendered identity is formed. Gender resides in the action and the repetition of the societal norms and codes of masculinity and femininity. So as to be defined as feminine, the female has to embrace the sets of actions and behaviors assigned to femininity, and the male should in the same way adjust himself to the codes of masculinity. Hence, argues Butler "gender is always a doing...there is no gender identity behind the expressions of gender; that identity is performatively constituted by the very 'expressions' that are said to be its results" (1999, p. 33).

It is here, then, within the societal codes of gender that subordination of women takes place. The codes for femininity inside the framework of the western and many other different cultures are set on the "assumption that women must 


\section{QALAAI ZANISTSCIENTIFIC JOURNAL \\ A Scientific Quarterly Refereed Journal Issued by Lebanese French University - Erbil, Kurdistan, Iraq \\ Vol. (6), No (1), Winter 2021 \\ ISSN 2518-6566 (Online) - ISSN 2518-6558 (Print)}

define themselves as the caring sex" (Seigfred, 1989, p.68, cited by O'Grady, 2005, p. 28).

Starting from a young age, little girls are taught to look after the opposite sex and to nurture tits emotional needs an inclination that is little acknowledged by society. This sense of responsibility towards meeting the needs of the opposite sex leads to an identity that is "other-oriented" in women. The process of building an ethics of care towards the other, leads to an absence of the caring for the self in women. Thus, the problem does not lie in the action of caring for the other; rather, it is this lack of care for the self that becomes problematic. It leads women to psychologically accept the fact that the other should come first while they should come second which in turn causes a lack of reciprocity in relationships (O'Grady, 2005, p. 28). Hereby, the man's needs are surely going to be met, while the woman should take it as a matter of fact that even if her emotional needs are not nurtured, this is how relationships work.

In the case of Fefu, the effect of these social aspects of gender becomes clear with the presence of the rifle. Hughes notes that "Fornes makes it clear...that Fefu's conflict is not entirely internal. That double-barrel shotgun, described even in the opening stage direction, is a very real, violent presence throughout the play" (2000, p. 2). Ullman (2000) moreover argues that the gun is "a masculine, violent way for Fefu to release her anguish over her failing marriage". Fefu knows that she is losing her husband but she refuses to take on feminine characteristics and mourn over his loss. Fefu's struggle with the codes of femininity society imposes on women is reflected in her attempt to devour herself into activities generally held to be masculine. She preoccupies herself with actions such as shooting, plumbing, and, hunting all of which are considered non-feminine activities by the society. As a feminist, Fefu refuses to be submissive, unlike Christina and Cindy who avoid any thought that places them out of their comfort zone. Being domestic is what a woman is supposed to be inside the framework of patriarchy. When at the end of the play Fefu grabs the 


\section{QALAAI ZANISTSCIENTIFIC JOURNAL}

A Scientific Quarterly Refereed Journal Issued by Lebanese French University - Erbil, Kurdistan, Iraq

Vol. (6), No (1), Winter 2021

ISSN 2518-6566 (Online) - ISSN 2518-6558 (Print)

rifle and goes outside Christina remarks “I don't care if you shoot yourself. I just don't like the mess you're making" (Fornes, 1978, p. 140).

It can thus be said that the struggle for an identity free from the shackles of societal gender norms is at the heart of Fornes' play. All the characters "must strive to create an identity not dependent on men (or "man") for its definition, one that celebrates both the plumbing that women can call their own and the fact that women can do all their 'own plumbing'" (Murray, 2009).

\section{Conclusion}

Fornes' play with its all-female cast emphasizes the importance of women's relationship to each other. It leaves the reader perplexed and unable to provide an adequate answer to the fate of its characters. This in itself shows Fornes' insistence to exhibit and portray women's situation and their internal struggles as it is. Rather than providing a solution for the situation of its characters, Fornes' play provides the reader with serious thoughts and considerations, eye opening images, brave admittances, and bitter confrontations with the current reality of the situation of women as it is. She shows the negative, sad, and even the tragic result of standing approaches to women and the nature of femininity. By implication, she boosts and encourages the suggested solutions provided by the French Feminists.

\section{REFERENCES:}

Barry, P. (2009). Beginning theory: An Introduction to Literary and Cultural Theory. Manchester: Manchester University Press.

Bertens, H. (2008). Literary Theory: The Basics. $2^{\text {nd }}$ ed. London: Routledge.

Bowlby, R. (1989) In: Brennan, T., ed., Between Feminism and Psychoanalysis. London: Routledge, p.48.

Braidotti, R. (1989). 'The Politics of Ontological Difference'. In: Brennan, T.,

(ed.), Between Feminism and Psychoanalysis. London: Routledge, pp. 89-102.

Brennan, T. ed., (1989). Between Feminism and Psychoanalysis. London:

Routledge, pp.1-14.

Bressler, C. (2011). Literary criticism. Boston: Pearson Longman. 


\section{QALAAI ZANISTSCIENTIFIC JOURNAL \\ A Scientific Quarterly Refereed Journal Issued by Lebanese French University - Erbil, Kurdistan, Iraq \\ Vol. (6), No (1), Winter 2021 \\ ISSN 2518-6566 (Online) - ISSN 2518-6558 (Print)}

Buhle, M. J. (1998). Feminism and its Discontents: A Century of Struggle with Psychoanalysis. Cambridge, Massachusetts: Harvard University Press.

Butler, J. (1999). Gender Trouble: Feminism and the Subversion of Identity. New York: Routledge.

Cixous, H., Clement, C. (1986). The Newly Born Woman. Translated by B. wing. Manchester: Manchester University Press.

Dobie, A. B. (2015) Theory into Practice: An Introduction to Literary Criticism. Stamford: Cengage Learning.

Ehlers, N. (2016). 'Identities'. In: L. Disch and M. Hawkesworth, ed., The Oxford Handbook of Feminist Theory. New York: Oxford University Press, pp.346-366.

Fornes, M. (1978). 'Play: Fefu and Her Friends'. Performing Arts Journal, 2(3), pp. 112 140.

Gilligan, C. (1993). In a different voice. Cambridge, MA: Harvard University Press.

Guerin, W. Labor, E., Morgan, L., Reesman, J. and Willingham, J. (2011). A Handbook of

Critical Approaches to Literature. $6^{\text {th }}$ ed. Oxford: Oxford University Press.

Hughes, D. (2000). Fefu and Her Friends (1977) - Long Pauses. [online] Longpauses. com.

Retrieved from https://www.longpauses.com/fefu-and-her-friends-1977/

[Accessed

Dec, 2018]

Irigaray, L. (1993a). Je, Tu, Nous: Toward a Culture of Difference. Translated by A.

Martin. London: Routledge.

Irigaray, L. (1993b). An Ethics of Sexual Difference. Translated by C. Burke and C. Gill.

New York: Cornell University Press.

Irigaray, L. (2004). 'The Power of Discourse and the Subordination of the Feminine'. In:

Rivkin, J. and Ryan, M. ed., (2004). Literary Theory: an Anthology. 2nd ed. Malden,

MA: Blackwell Publishing, pp. 795-799.

Kahn, C. (2004). 'The Hand That Rocks the Cradle'. In: Rivkin, J. and Ryan, M. ed., Literary Theory: an Anthology. 2nd ed. Malden, MA:

Blackwell Publishing, pp. 826-834.

Marks, E. and De Courtivron, I. (1981). New French Feminisms. New York: Schocken Books.

Mitchell, J. (2000). Psychoanalysis and Feminism: A Radical Reassessment of Freudian

Psychoanalysis. New York: Basic Books.

Murray, P. (2001). Fefu and Her Friends (Encyclopedia.com). [online] Available at:

https://www.encyclopedia.com/arts/educational-magazines/fefu-and-her-friends

[Accessed

8 Feb 2018]. 


\section{QALAAI ZANISTSCIENTIFIC JOURNAL}

A Scientific Quarterly Refereed Journal Issued by Lebanese French University - Erbil, Kurdistan, Iraq

Vol. (6), No (1), Winter 2021

ISSN 2518-6566 (Online) - ISSN 2518-6558 (Print)

O'Grady, H. (2005). Woman's Relationship with Herself: Gender Foucault and Therapy. London: Routledge.

Rivkin, J. and Ryan, M. ed., (2004). Literary Theory: an Anthology. 2nd ed. Malden, MA: Blackwell Publishing, pp.389-396.

Robinson, M. (1997). The Other American Drama. Baltimore, Md: Johns Hopkins University Press.

Saddik, A. (2007). Contemporary American Drama. Edinburgh: Edinburgh University Press.

Shibley Hyde, J. and Beth Oliver, M. (2000). Gender Differences in Sexuality: Results from Meta-analysis. In: C. Brown Travis and J. W. White, ed., Sexuality, Society, and Feminism. Washington, DC: American Psychological Association, pp.57-77.

Stone, A. (2016). 'Sexual Difference'. In: L. Disch and M. Hawkesworth, ed., The Oxford

Handbook of Feminist Theory. New York: Oxford University Press, pp.874-893.

Tong, R. (2014). Feminist thought. 4th ed. Boulder: Westview Press.

Tyson, L. (2015). Critical theory today. 3rd ed. London: Routledge.

Ullman, C. (2008). Fefu and Her Friends (Encyclopedia.com). [online] Retrieved from

https://www.encyclopedia.com/arts/educational-magazines/fefu-and-her-friends [Accessed

8 Feb 2018].

Vice, S. (1998). 'Psychoanalytic Feminist Theory'. In: S. Jackson and J. Jones, ed., Contemporary Feminist Theories. Edinburgh: Edinburgh University Press, pp.162-176.

Vigoya, M.V. (2016). 'Sex/Gender'. In: L. Disch and M. Hawkesworth, ed., The Oxford Handbook of Feminist Theory. New York: Oxford University Press, pp.852-873.

Wilson, E. and Goldfarb, A. (2000). Living Theatre: A History. 3rd ed. Boston: McGraw Hill.

Zakin, E. (2011). Psychoanalytic Feminism (Stanford Encyclopedia of Philosophy). [online]. Plato.stanford.edu. Retrieved from https://plato.stanford.edu/entries/feminism psychoanalysis/. [Accessed 18 Oct, 2018].

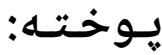

يرسى گهيشتن به كهسايهتييهكى تايبهت به ميّيينه و دهنكيّك و ناسنامهيهك كه گوزارشت له خودى ههر تاكيّكى ميّينه دهكات دوور لهو ديدكايانهى كه وا ميّيينه وهك لايهنه تهواوكراوهكهى نيّرينه بهرجهسته دهكه، ههميشه بريتى بووه له يهكيك له تهوهره سهركييهكانى فيّمينيزم. 


\section{QALAAI ZANISTSCIENTIFIC JOURNAL}

A Scientific Quarterly Refereed Journal Issued by Lebanese French University - Erbil, Kurdistan, Iraq

Vol. (6), No (1), Winter 2021

ISSN 2518-6566 (Online) - ISSN 2518-6558 (Print)

له كَلْ ئهوهشدا، له كَلْ دةسيِّكى رِيّبازى دهروونشيكارى و بهرفراوانبوونى له نيّو جيهانى تيوّرى و ئهدهبدا، بيرمهند و بانكخوازانى سهر به فيمينيزم له كوّتاييدا كهيشتن بهو سهرجاوه و تيوّريانهى كهوا تيّروانينيّكى زياتريان يِّ دهبهخشيّت بوّ گهيشتن به تيّكهيشتنيّكى تهواو بوّ سروشتى ميّينه كه وا له ريّكايهوه بتوانن ئه گهرى دارشتنى خوديّكى سهربه خوّ بكهن بوّ تاكى رئى ميّيينه وه له ههمان كاتدا دهستنيشانى ئهو كوّسيانه بكهن كهوا ريّكًا له بهربلاّوبوونى كهسايهتيهكى تايبهت به ميّينه دهكه. فيّمينيزمى دهروونشيكارى كه بريتييه له خالّى سهرهكى ئهم تويَزينهوهيه، جهخت له سهر دانهيالِيهكى بيردوّز و رِيساكانى ههر يهك له رِيِبازهانى فيّمينيزم و دهروونشيكارى دهكات بوّ تيشك خستنه سهر ئهو ويَنه نه كوّرانهى كه وا له ناخى تاكهكانى كوّمهلّكا جههياون دهربارهى رِكَهز كه وا له ئهنجامدا بهردهوامى به باوك سالارى

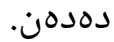
ئهم تويّزينهوهيه جِوّنيهتى كارليّكى نيّوان فيّمينيزم و ريّبازى دهروونشيكارى دهخاته رِوو له رِيّكاى لِيكوَّلَينهوهيهكى باس ريشهيى بوّ شانوّى فيّفو و هاورِيّكانى (1977) تايبهت به شانوّساز ماريا ئايرين فؤرنيّس. ئهم شانوّيه كهوا دهستهى شانوّكارانى تهنها له رِكهزى ميّيينهن، ئهو كيّشه جيا جيايانه دهخاته رووو كهوا روو به رووى ميّيينه دهبنهوه له كوّمهلّكايهكى باوك سالاردا.

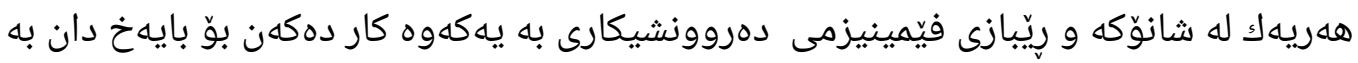
جهمكى رِّكهز و يِيكهاته بايوّولوجيهكهى وه ههروهها جِوّنيهتى تيّروانينى ئافرهت بوّ خؤى و سروشتى يهيوهندى ئافرهت له كهل خودى خوّى و ئافرهتانى دهوروبهر.

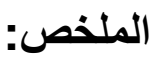

طرح مسألة التوصل الى هوية خاصة بالأنثى والتي تعبر عن آمالها و تطلعاتها و شخصيتها التي تجسد

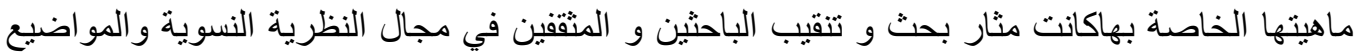

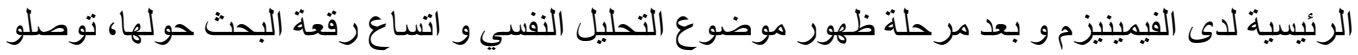

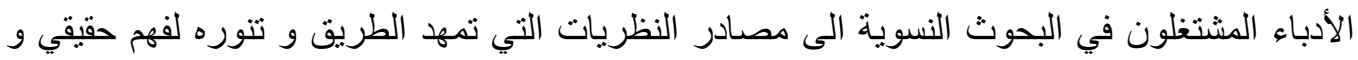

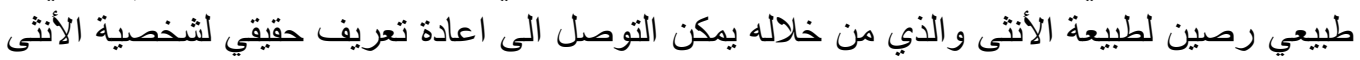




\section{QALAAI ZANISTSCIENTIFIC JOURNAL}

A Scientific Quarterly Refereed Journal Issued by Lebanese French University - Erbil, Kurdistan, Iraq

Vol. (6), No (1), Winter 2021

ISSN 2518-6566 (Online) - ISSN 2518-6558 (Print)

و الحد دون تدخل الآخرين لدور الأنثى و منعها من استقلاليتها. و تعد نظرية التحليل النفسي النسوي التي الني

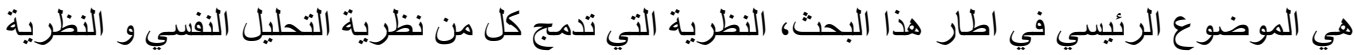

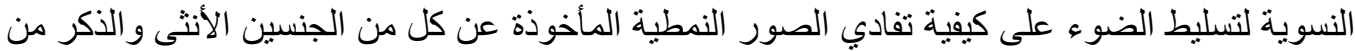

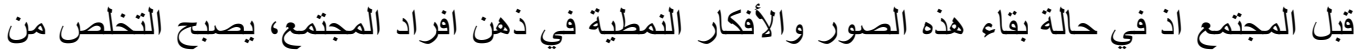

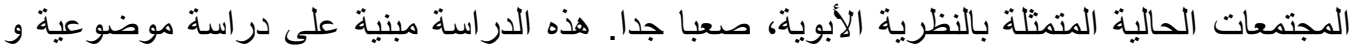

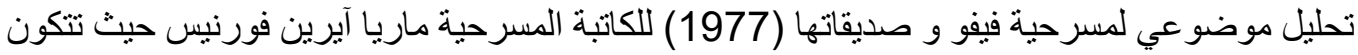

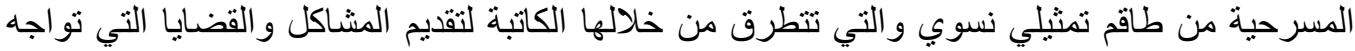
المر أة في المجنمعات الأبوية. 